\title{
A Combined effect of antimicrobial edible coatings with reduction of initial microbial load on the shelf-life of fresh hake (Merluccius merluccius) medallions
}

\author{
32 Víctor Otero-Tuárez, ${ }^{1,2}$ (D) Ximena Carrión-Granda, ${ }^{3}$ Idoya Fernández-Pan, ${ }^{4}$ Teresa Fernández ${ }^{2}$ \& Juan I. Maté2* \\ 1 Faculty of Agricultural Sciences, Universidad Laica Eloy Alfaro de Manabí, 130214 Manta, Ecuador \\ 2 Department of Agronomy, Biotechnology and Food, Universidad Pública de Navarra, 31006 Pamplona, Spain \\ 3 S.A. R+D Department, Viscofan, Polígono Industrial Berroa, C/Berroa 15-4, Tajonar, 31192 Navarra, Spain \\ 4 BCC Innovation, Basque Culinary Center, Paseo Juan Avelino Barriola, 101, 20009 Donostia-San Sebastian, Spain
}

(Received 24 July 2018; Accepted in revised form 10 October 2018)

\begin{abstract}
Summary
Two distinct strategies were combined to preserve fresh fish (Merluccius merluccius) under refrigeration at $4{ }^{\circ} \mathrm{C}$ for 12 days: (i) the application of an antimicrobial edible coating enriched with oregano essential oil $(\mathrm{OEO})$ or carvacrol $(\mathrm{CV})$ and (ii) the reduction of initial microbial load by good handling practise and the use of sodium hypochlorite $(\mathrm{NaOCl})$. The action of antimicrobial coatings alone retarded the growth of Enterobacteriaceae, lactic acid bacteria (LAB) and $\mathrm{H}_{2} \mathrm{~S}$ producing bacteria on fish samples. The reduction of initial microbial load by itself only affected the evolution of LAB, but not the rest of the bacterial groups. When using both techniques combined, edible antimicrobial coatings were significantly more effective with additional and significant delays in the growth of mesophilic, psychrotrophic and Pseudomonas bacteria. Thus, the use of both strategies combined resulted in a reduction of the counts of all bacterial groups after 12 days of storage which ranged from $1.5 \log$ and $8 \mathrm{log}$, in Pseudomonas and $\mathrm{H}_{2} \mathrm{~S}$ producing bacteria, respectively. Moreover, no significant differences were observed when comparing the microbiological evolution of samples treated with OEO compared to those only treated with CV.
\end{abstract}

Keywords

Antimicrobial edible coating, combined effect, initial microbial load, $\mathrm{NaOCl}$, refrigerated hake, whey protein isolate.

\section{Introduction}

Fresh fish is a highly perishable food product, thus, increasing its shelf-life is crucial for this industry. The major cause of deterioration is bacterial growth. The fresh fish industry has been applying a number of preservation technologies to reduce the proliferation of microorganisms. Disinfection is one of the strategies employed to reduce the bacterial load on fresh fish. $\mathrm{NaOCl}$ is used as a disinfectant in the Fish Industry. Chlorinated water is widely used for both washing fish and cleaning processing surfaces and is recommended by International Organizations (FAO/WHO, 2008). The most commonly used forms of chlorine in the fish industry are $\mathrm{Ca}(\mathrm{ClO})_{2}$ and $\mathrm{NaClO}$. The bactericidal effect of chlorinated water is based on its strong, penetrating, oxidising action on the enzyme system of the bacterial cell (Bremer \& Osborne, 1998). The concentration of chlorine used in the fish industry depends on the fish species and the target microorganism.

*Correspondent: E-mail: victor.otero@uleam.eduec
Thus, Bremer \& Osborne (1998) described that water containing free chlorine at $200 \mathrm{mg} \mathrm{L}^{-1}$ could eliminate over $99 \%$ of Listeria monocytogenes in King Salmon. A similar procedure was reported to control L. monocytogenes in shrimp (FAO/WHO, 2008). Other preservation technologies that are commonly used to extend the shelf-life of fresh fish include refrigeration (around $4{ }^{\circ} \mathrm{C}$ ) along with modified atmosphere packaging (MAP).

The use of edible antimicrobial coatings in fish preservation has been proposed as a new tool to control food microbial growth. Antimicrobial edible coatings are formed directly on the fish product, maintaining a high concentration of the active compounds where they are most need especially necessary, that is, on the fish surface. Edible coatings are made of a wide variety of raw materials which include polysaccharides, proteins and lipids (Kilincceker et al., 2009). Edible coatings based on whey protein isolate (WPI) are considered to be good barriers to oxygen, lipids and odours. In addition, WPI is characterised to 
be an excellent emulsifier which makes it a suitable matrix for hydrophobic compounds including many antimicrobial agents such as select essential oils (Bakkali et al., 2008).

Essential oils are natural mixtures of chemical compounds biosynthesized by plants, such as terpenes, alcohols and ketones (Bakkali et al., 2008). Due to its antimicrobial properties, essential oils have been used to enrich edible films and coatings. Essential oil compounds including $\mathrm{CV}$, thymol and eugenol have been identified to exhibit antibacterial characteristics (Burt, 2004). Gram-negative bacteria are generally less susceptible to essential oils than gram-positive ones. A recent study (Carrión-Granda et al., 2017) evaluated the antimicrobial activity of two major active compounds (thymol and CV) present in the essential oils oregano and thyme against twelve bacteria related to the spoilage of fish products. The results of this study exhibited a greater efficacy of CV than thymol. On the other hand, the two active compounds had a lower bacterial inhibition capacity compared to their corresponding essential oil, possibly due to a synergistic effect of CV and thymol with some of the other compounds that are part of the Oregano and/or Thyme essential oil extracts. It is essential to assess whether or not these same differences hold true in an in vitro situation. Thus, an in vitro evaluation is included in the present research.

Antimicrobial edible coatings with essential oils incorporated have been applied to fish for shelf-life studies. Pyrgotou et al. (2010) evaluated the effect of OEO combined with MAP on fresh rainbow trout fillets stored at the refrigeration temperature of $4{ }^{\circ} \mathrm{C}$ for 21 days. These authors observed Enterobacteriaceae, $\mathrm{LAB}$ and $\mathrm{H}_{2} \mathrm{~S}$ producing bacteria growth inhibition. Hosseini et al. (2016) studied the effect of a fish gelatine coating containing OEO on the shelf-life of rainbow trout fillets under refrigeration. A significant delay in the growth of mesophilic bacteria was demonstrated.

Most of these shelf-life studies did not consider the initial microbial load of the fresh fish to be a factor, which could have influenced the results. According to the International Commission on Microbiological Specifications for Foods, most aquatic animals at the time of harvest had microbial counts in the range of $10^{2}-10^{5} \mathrm{CFU} \mathrm{g}^{-1}$ (ICMSF, 2005). Özean \& Erkmen (2001) studied the antimicrobial activity of the essential oils of nine plants spices, among them OEO, against ten bacterial strains involved in food spoilage. They concluded that all food products require a very low initial microbial load for increased shelf-life when using essential oils. Another recent study (CarriónGranda et al., 2018) evaluated the effect of a WPI based coating enriched with oregano or thyme essential oils in combination with MAP technology on the shelf-life of hake fillets. When special hygienic care was taken with the fillets during cleaning and deboning, an initial lower microbial load was accomplished. This initial reduced microbial load was illustrated to significantly improve the effectiveness of the posterior treatments. Therefore, it is necessary to evaluate the influence on the effectiveness of the coatings when a greater reduction of the initial microbial load is achieved.

Thus, the main objective of this research was to study the effect of an antimicrobial WPI based coating on the shelf-life of fresh hake medallions with various levels of initial microbial loads. A second objective was to compare the two antimicrobial agents, OEO with $\mathrm{CV}$, in order to confirm the possible synergistic effect of the other components constituting OEO on the evolution of the microbiological quality of fresh hake.

\section{Materials and methods}

\section{Materials}

Davisco Food International (Le Seur, MN, USA) provided the WPI. Panreac Química S.A. (BarcelonaSpain) provided the glycerol and $\mathrm{NaOCl}(10 \% \mathrm{w} / \mathrm{v})$. Esencias Martínez Lozano S.A. (Murcia-Spain) provided the OEO (Origanum vulgaris) with the following composition: $72.23 \% \mathrm{CV}, 2.19 \%$ thymol and $0.02 \%$ Eugenol. Sigma-Aldrich (Madrid-Spain) supplied the $\mathrm{CV}$, the main active compound of OEO.

\section{Preparation of hake medallions}

Three types of hake medallions (M. merluccius) with different microbial loads were used for tests A, B and C. Test A corresponded to the least strict hygienic conditions whereas test $\mathrm{C}$ the most intense one. To complete each test, eight hake individuals of average weight of $0.70 \mathrm{Kg}$ and average length of $35 \mathrm{~cm}$ were necessary. In all cases, fresh hake was purchased from a local fishery in Pamplona, Spain and transported in a cooler filled with ice to our lab. For test A, the hake was eviscerated and filleted at the fish market and medallions were obtained aseptically (inside a laminar flow chamber) in the laboratory. For test B, whole eviscerated hake was purchased then filleted and cut to obtain medallions aseptically in our lab inside a laminar flow chamber. For test $\mathrm{C}$, pieces of whole hake were acquired in the market and taken to the lab where they were first submerged for $1 \mathrm{~min}$ in $15 \mathrm{~L}$ of cold water (approximately $4 \pm 2{ }^{\circ} \mathrm{C}$ ) containing $250 \mathrm{mg} \mathrm{L}^{-1}$ of $\mathrm{NaOCl}$; then the pieces of hake were eviscerated and washed with tap water and finally filleted and cut to obtain medallions inside a laminar flow chamber. For the three tests, the medallions 
employed weighed approximately $25 \mathrm{~g}$ each. Three medallions were prepared per sample.

\section{Preparation of the antimicrobial film-forming solutions (FFS)}

Three hundred milli litre of FFS was prepared for each treatment following the procedure described by Carrión-Granda et al. (2018). Firstly, a solution of WPI at $10 \%(\mathrm{w} / \mathrm{w})$ and glycerol at $5 \%(\mathrm{w} / \mathrm{w})$ in distilled water was prepared was added as a plasticizing medium. The solution was heated in a water bath at $90{ }^{\circ} \mathrm{C}$ for 30 min under constant stirring after which it was cooled to room temperature. Then, $\mathrm{OEO}$ or $\mathrm{CV}$ was added at 3 or $2.16 \%(\mathrm{w} / \mathrm{w})$ respectively. The amount of $\mathrm{CV}$ corresponded to its concentration in a $3 \%$ OEO solution. Finally, FFS were homogenised by sonication (UP 400, HUT, Germany) using a $7 \mathrm{~mm}$ diameter tip for $5 \mathrm{~min}$ at $100 \%$ amplitude. During sonication each FFS was maintained in an ice water bath to avoid temperature raises over $30^{\circ} \mathrm{C}$.

\section{Preparation of coated samples}

For the coating, each fish medallion was first dipped in $150 \mathrm{~mL}$ of FFS for $1 \mathrm{~min}$; the excess FFS was allowed to drip off for $45 \mathrm{~s}$, and samples were then dried for 5 min under an air stream. After this process, the medallions were dipped again in the FFS for $1 \mathrm{~min}$, drained for $45 \mathrm{~s}$ and dried again under an air stream for $30 \mathrm{~min}$. The coated fish samples plus controls were packaged in polypropylene trays, heatsealed and stored at $4{ }^{\circ} \mathrm{C} \pm 1{ }^{\circ} \mathrm{C}$ for 12 days.

In each test, three replicates were established for each treatment. Each replicate consisted of one fish medallion. The experimental groups were as follows: (i) Control group (C): uncoated hake medallions; (ii) WPI group: hake medallions coated with FFS without OEO or CV; (iii) WPI + OEO group: hake medallions coated with FFS enriched with 3\% OEO and (iv) WPI + CV group: hake medallions coated with FFS enriched with $2.16 \% \mathrm{CV}$.

\section{Microbiological analysis}

At days $0,4,8$ and 12 of storage, fish samples from the three trials (A, B and C) of each of the treatments were collected for microbiological analysis. Hake medallions were aseptically weighed, placed in sterile plastic bags (BagPage, Interscience-France) and homogenized with $225 \mathrm{~mL}$ of buffered peptone water $\left(\mathrm{pH} 7 \pm 0.1\right.$ at $\left.25^{\circ} \mathrm{C}\right)$ (Cultimed, Spain) using a stomacher (Stomacher 400, London-UK) for 2 min. Decimal dilutions were prepared which were then seeded on the surface of culture media (agar) using a spiral planter (Eddy Jet 2 for spiral seeding
IUL, USA). Table 1 describes the microorganisms that were evaluated for each sample. The results were expressed in $\log \mathrm{CFU} \mathrm{g}^{-1}$. The maximum growth ranges will be in accordance with the European Regulations (EC, 2005). In addition, values $<1$ $\log \mathrm{CFU} \mathrm{g}{ }^{-1}$ are considered to have an undetectable concentration of microorganisms.

\section{Data analysis}

All tests were performed in triplicate. The statistical analysis was performed using SPSS software (SPSS Inc., Chicago, IL., USA). Duncan's multiple range test was used to observe significant differences $(P \leq 0.05)$ between the means of the variables.

\section{Results and discussion}

\section{Microbiological quality of fresh fish}

The microbiological quality of fresh hake medallions (uncoated control group) was evaluated at time zero in test A, B and C. As shown in Fig. 1, the counts of all bacterial groups except LAB, were significantly lower $(P<0.05)$ in test $\mathrm{C}$ samples and significantly higher $(P<0.05)$ in the test A samples; in all cases, intermediate values were found for the samples from test B. In the case of $\mathrm{LAB}$ the growth was $<1 \log \mathrm{CFU} \mathrm{g} \mathrm{g}^{-1}$ at time zero for the three tests. In addition, for all of the tests the counts of mesophilic bacteria did not exceed the legal limit for marketing (6 log CFU g $\left.{ }^{-1}\right)$, according to the current legislation (European Commission, 2005). However, total counts of Enterobacteriaceae in test $\mathrm{A}\left(4.27 \log \mathrm{CFU} \mathrm{g}{ }^{-1}\right)$ and in test $\mathrm{B}$ (3.19 $\log$ CFU ${ }^{-1}$ ) exceeded the maximum legal amount for commercialisation $\left(3 \log \mathrm{CFU} \mathrm{g}{ }^{-1}\right)$; this was not the case for test $\mathrm{C}\left(<1 \log \mathrm{CFU} \mathrm{g} \mathrm{g}^{-1}\right)$. When applying a $\mathrm{NaOCl}$ solution as a surface disinfectant (test $\mathrm{C}$ ), the initial microbiota present on the surface of the fish

Table 1 Microorganisms associated with fish spoilage and culture conditions

\begin{tabular}{|c|c|c|}
\hline Microorganisms & Culture medium & Incubation \\
\hline Enterobacteriaceae & $\begin{array}{l}\text { Violet red bile } \\
\text { glucose agar (VRBG) }\end{array}$ & $37^{\circ} \mathrm{C} ; 24 \mathrm{~h}$ \\
\hline Mesophilic bacteria & $\begin{array}{l}\text { Plate counting } \\
\text { agar (PCA) }\end{array}$ & $30{ }^{\circ} \mathrm{C} ; 48 \mathrm{~h}$ \\
\hline Psychrotrophic bacteria & $\begin{array}{l}\text { Plate counting } \\
\text { agar (PCA) }\end{array}$ & $5^{\circ} \mathrm{C} ; 7$ days \\
\hline Pseudomonas spp. & $\begin{array}{l}\text { Pseudomonas } \\
\text { Agar (PS Agar) }\end{array}$ & $30^{\circ} \mathrm{C} ; 48 \mathrm{~h}$ \\
\hline Lactic acid bacteria & $\begin{array}{l}\text { De Man, Rogosa } \\
\text { and Sharpe Agar (MRS) }\end{array}$ & $30{ }^{\circ} \mathrm{C} ; 5$ days \\
\hline $\mathrm{H}_{2} \mathrm{~S}$ producing bacteria & Iron Agar (IA) & $30^{\circ} \mathrm{C} ; 48 \mathrm{~h}$ \\
\hline
\end{tabular}


was considerably reduced, thus, minimising the contamination of the hake medallions during filleting. Therefore, the bacterial load present on fish skin was demonstrated to be critical for the microbiological quality of fresh medallions.

As is commonly known, live and healthy fish do not contain microorganisms in their flesh. Microorganisms are only located on their skin, gills and digestive track (Boziaris \& Parlapani, 2017). Aponte et al. (2018) reported microorganism values higher than 3 log CFU cm $\mathrm{cm}^{-2}$ on the skin of $\operatorname{cod} 2$ days after fishing. These authors also quantified how flesh was being contaminated during preparation of fish samples. Thus, if microbial load on the fish surface is reduced, the microbial quality of processed fish would be improved as illustrated in our results.

The total counts of microorganisms in fresh fish from test $\mathrm{A}$ at time zero were similar to the results reported by Carrión-Granda et al. (2018), who used fresh hake filleted at the fish market. This author reported the presence of mesophilic, psychrotrophic bacteria and Pseudomonas spp. at very high levels ( $>5$ $\log \mathrm{CFU} \mathrm{g}^{-1}$ ). Ozogul \& Uçar (2013) used fresh fish filleted at the fishery to evaluate the antimicrobial activity of different essential oils, and also observed at the beginning of the test for the control group, total counts of mesophilic bacteria and psychrotrophic bacteria $>5 \log$ CFU g ${ }^{-1}$. In addition, Bensid et al. (2014) reported values related to the growth of mesophilic and psychrotrophic bacteria similar to those reflected in test B; likely due to the fact that the fresh fish was filleted under laboratory conditions. In test $\mathrm{C}$ of the present study, the initial concentrations of mesophilic bacteria (3.53 log CFU g ${ }^{-1}$ ) and psychrotrophic bacteria (3.21 $\log \mathrm{CFU} \mathrm{g^{-1 }}$ ) were significantly lower than those reported in the previous studies, although similar to the ones reported by Jasour et al. (2015). In this research the uncoated fresh fish medallions were immersed in purified water, likely reducing the initial microbial load.

\section{Shelf-life of uncoated samples}

The evolution of the microbial quality of uncoated fish samples with distinct levels of initial microbial load is shown in Fig. 1. In most of the bacterial groups
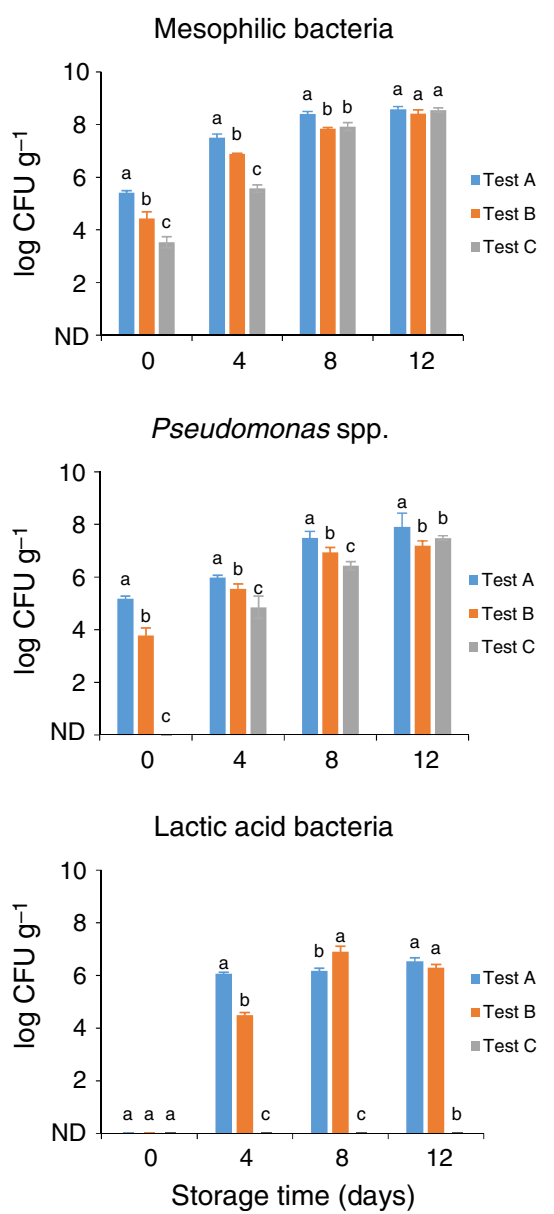
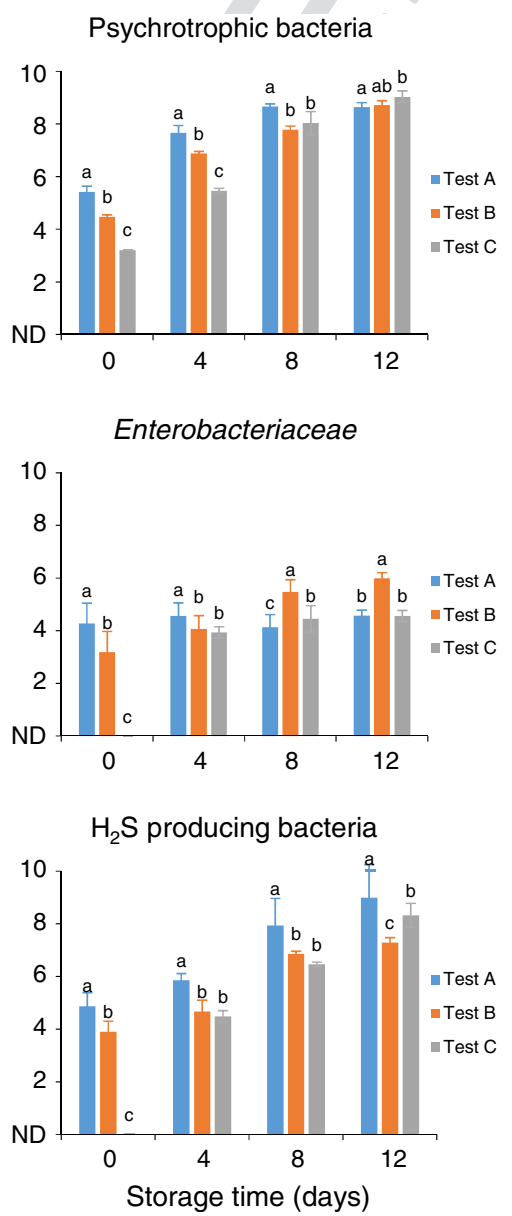

Figure 1 Total microorganism counts (log $\mathrm{CFU} / \mathrm{g}$ ) associated with fish spoilage in samples of fresh uncoated hake (control group) during 12 days at $4{ }^{\circ} \mathrm{C}$. Test $\mathrm{A}$, fish filleted at the fish market. Test B, fish filleted in laboratory. Test $\mathrm{C}$, fish eviscerated and filleted in laboratory. Different letters (a, b and c) indicate significant differences in each bacterial group. ND, non-detectable. 
studied (except LAB), the differences in microbial counts observed at time zero among tests were not maintained after 8 or 12 days storage at $4{ }^{\circ} \mathrm{C}$. Therefore, the growth rate of these bacteria groups in test $\mathrm{C}$ (most strict starting hygienic conditions) was faster than in samples from test A or B.

The counts for $\mathrm{LAB}$ were $\leq 1 \log$ at time zero for all of the tests. However, the evolution of the LAB growth was significantly different $(P<0.05)$ in test $\mathrm{C}$ compared to $\mathrm{A}$ or $\mathrm{B}$. In the former there was no detectable bacterial growth during the 12 days of the experiment. In tests $\mathrm{A}$ and $\mathrm{B}$ there was fast growth during the first 4 days and slower growth thereafter. The microbial concentration after 8 days was in both cases $\geq 6 \log$ indicating a quite intense contamination.

Thus, the presence of LAB bacterial group could be controlled by implementing an improvement of the hygienic conditions during handling and processing and performing a surface disinfection treatment (with $\mathrm{NaOCl}$ solution) on the whole fish. However, this approach was not enough to increase shelf-life longer than 4 days, since it was not effective for the rest of the bacterial groups. An extra strategy, such as the use
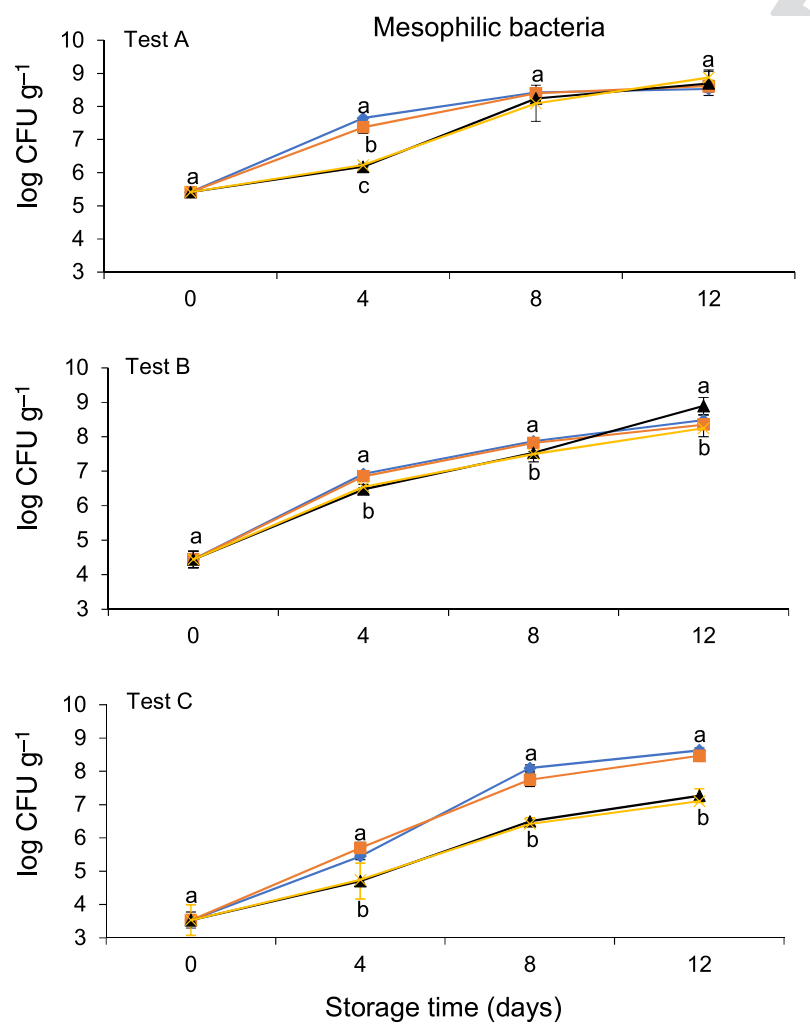

of an antimicrobial edible coating, would be needed to control microbial growth in fresh hake medallions and achieve a notable increase in shelf-life.

\section{Shelf-life of coated samples}

The evolution of the total counts of mesophilic bacteria on coated samples is shown in Fig. 2. In test A, during the first 4 days of storage, the proliferation of mesophilic bacteria was significantly lower $(P<0.05)$ in hake medallions coated with WPI + OEO or WPI $+\mathrm{CV}\left(>6 \log\right.$ CFU g $\left.{ }^{-1}\right)$, compared with the control group $\left(>7 \log \mathrm{CFU} \mathrm{g} \mathrm{g}^{-1}\right)$. However, after 8 or 12 days of storage, no differences were observed in the bacterial counts in the different treatments with or without edible coating. In test $\mathrm{B}$, there were no differences between the different treatments (with or without coating) in the evolutions of the microbial counts of mesophilic bacteria. Finally, in test $\mathrm{C}$, a significant $(P<0.05)$ delay of the growth of mesophilic bacteria after 4 days of storage was observed in samples with an antimicrobial coating $\left(\geq 4.70 \log \mathrm{CFU} \mathrm{g} \mathrm{g}^{-1}\right) \mathrm{com}$ pared to the control samples $\left(\geq 5.45 \log \mathrm{CFU} \mathrm{g} \mathrm{g}^{-1}\right)$.
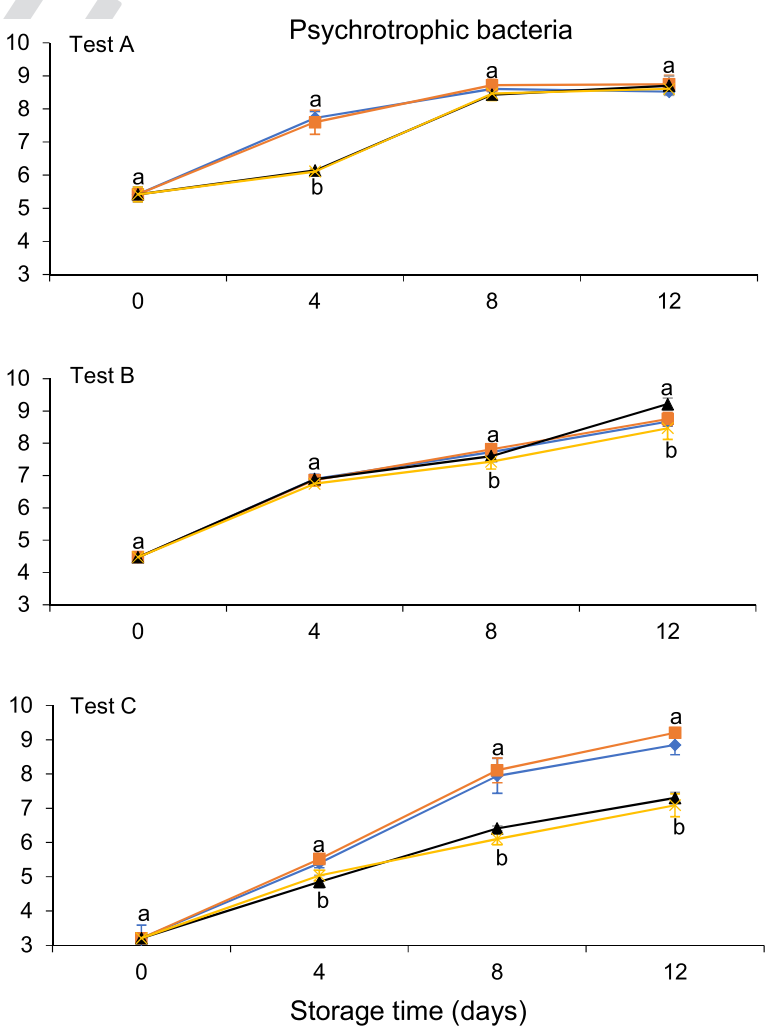

Figure 2 Total mesophilic and psychrotrophic bacteria counts (tests: A, B and C), during 12 days of refrigeration at $4{ }^{\circ} \mathrm{C}$. C: uncoated control; WPI, WPI coating; WPI + OEO, coating with WPI and OEO; WPI + CV, coating with WPI and CV. Different letters (a, b, c) indicate significant differences between treatments. WPI, Whey Protein Isolate; OEO, Oregano essential Oil; CV, Carvacrol; $\diamond-\mathrm{C}$; $\square-\mathrm{WPI}$;

$\Delta$-WPI + OEO; x-WPI + CV. 
This significant delay was maintained during the 12 days of storage (Fig. 2).

Similar behaviour was observed in the growth rate of the psychrotrophic bacteria (Fig. 2). Thus, for test A after 4 days of storage, total counts in the WPI + OEO and WPI + CV coated medallions were $>6 \log \mathrm{CFU} \mathrm{g} \mathrm{g}^{-1}$ and in the control samples $>7 \log$ CFU $\mathrm{g}^{-1}$. After 8 days of storage, there were no differences among samples. In test B, the same growth range was observed in all groups of treated medallions, with and without coating throughout the storage period. However, in test $\mathrm{C}$ there was a significant delay in psychrotrophic bacteria growth in fish samples with antimicrobial coatings from day $4 \quad(\geq 4.85 \quad \log$ CFU g $\left.{ }^{-1}\right)$ compared to control samples $(\geq 5.40 \mathrm{log}$ $\mathrm{CFU} \mathrm{\textrm {g } ^ { - 1 }}$ ). This delay was maintained during the 12 days of storage.

Pseudomonas spp. proliferation was considerably high (Fig. 3) in tests A and B. Antimicrobial edible coatings were not found to significantly affect the growth of Pseudomonas spp., when starting from a relatively high initial bacterial population. In test $\mathrm{C}$, with a lower initial microbial load, a significant delay
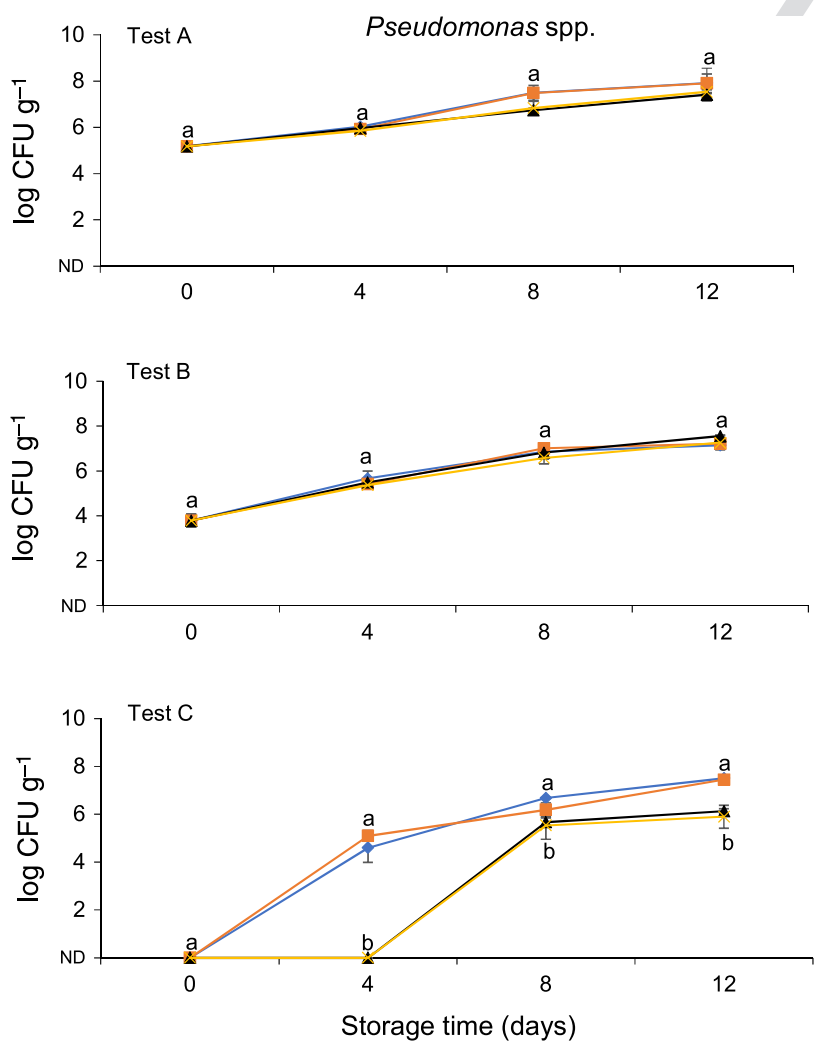

$(P<0.05)$ of Pseudomonas growth was observed in

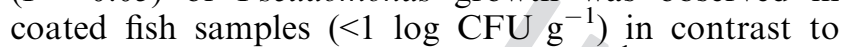
the control samples $\left(\geq 4.60 \log \mathrm{CFU} \mathrm{g}^{-1}\right)$ after 4 days of storage. This significant delay was maintained until day 12 of storage, although the absolute difference was lower (about $1.5 \log \mathrm{CFU} \mathrm{g}^{-1}$ ).

The results of the evolution of Enterobacteriaceae population in fish samples are shown in Fig. 3. The evolution of bacterial counts was similar for tests A and B. Thus, in both treatments, after 4 days of storage, although there were significant differences among treatments, the microbial quality in all samples was similar and above $>3 \log \mathrm{CFU} \mathrm{g}{ }^{-1}$; thus, no longer suitable for commercialisation (European Commission, 2005). The results for test $C$ showed that at time zero the counts of Enterobacteriaceae were very low $(<1 \log$

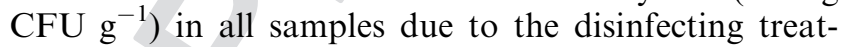
ment. From day 4 on, the growth of this bacterial

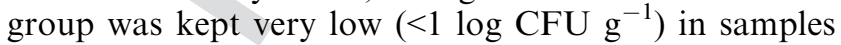
with an antimicrobial coating treatment. However, counts in Control groups $\left(\geq 3.80\right.$ log $\left.\mathrm{CFU} \mathrm{g}^{-1}\right)$ increased and were significantly higher than the treated samples as observed in Fig. 3. Thus, the effect of
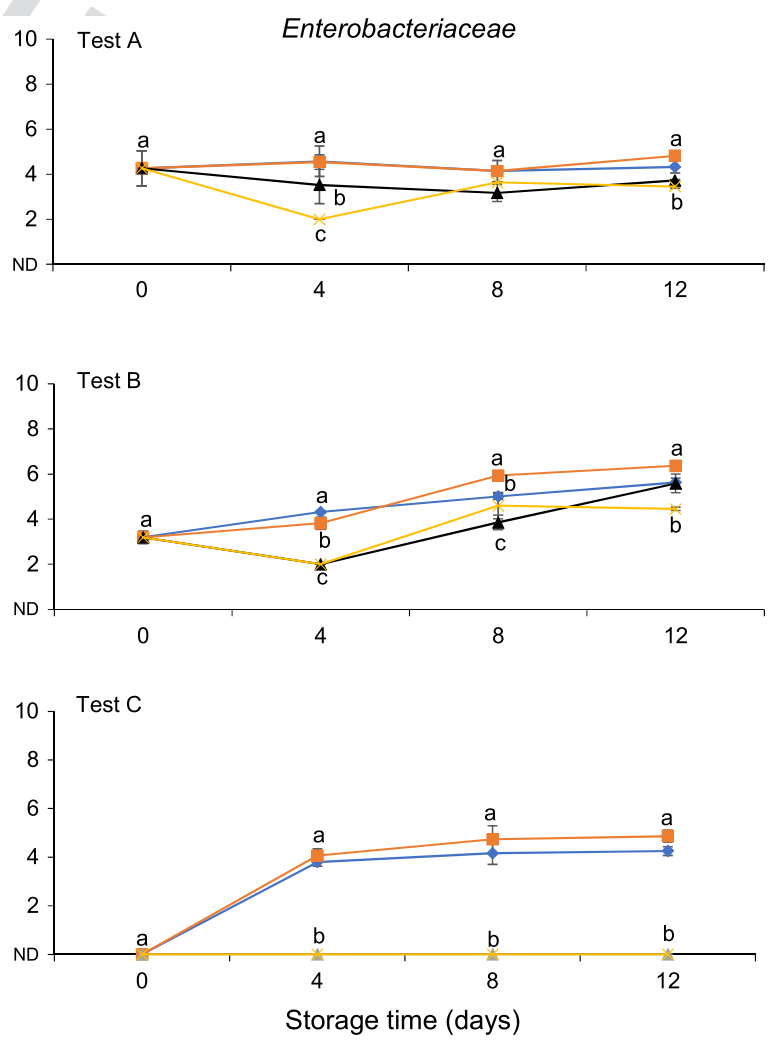

Figure 3 Total Pseudomonas spp., and Enterobacteriaceae counts (tests: A, B and C) for 12 days of refrigeration at $4{ }^{\circ} \mathrm{C}$. C: uncoated control; WPI, WPI coating; WPI + OEO, coating with WPI and OEO; WPI + CV, coating with WPI and CV. Different letters (a, b, c) indicate significant differences between treatments. WPI, Whey Protein Isolate; OEO, Oregano essential Oil; CV, Carvacrol; $-\mathrm{C}$; $=$-WPI; $\mathbf{\Delta}$-WPI + OEO; X-WPI + CV; ND, non-detectable. 
antimicrobial compounds on this bacterial group in test $\mathrm{C}$ was very notable.

The evolution of $\mathrm{LAB}$ counts are presented in Fig. 4. In tests $A$ and $B, L A B$ growth after 4 days of storage was statistically lower in fish samples with WPI + CV compared to that obtained in fish samples with WPI + OEO. In both cases the CFU counts were significantly lower than those from the control group. In both A and B this significant delay in samples with edible antimicrobial coatings was extended up to 12 days of storage $\left(>5 \log \mathrm{CFU} \mathrm{g}{ }^{-1}\right.$ ) as compared to the control group samples $\left(>6 \log \mathrm{CFU} \mathrm{g} \mathrm{g}^{-1}\right.$ ). In test $\mathrm{C}, \mathrm{LAB}$ growth was $<1 \log \mathrm{CFU} \mathrm{g} \mathrm{g}^{-1}$ in both fish samples with and without edible coating during the 12 days of storage. This was likely due to the disinfecting effect the $\mathrm{NaOCl}$ treatment had on the initial LAB population on the surface of the fresh fish.

The evolution of $\mathrm{H}_{2} \mathrm{~S}$ producing bacteria is also shown in Fig. 4. In test $\mathrm{A}$, the proliferation of these bacteria on fish samples with antimicrobial coating (with OEO or $\mathrm{CV}$ ) was significantly lower than that on the control samples. This was the case during the whole 12 days of storage. At day 12, the count difference between the treated and control samples was higher than $2.5 \log \mathrm{CFU} \mathrm{g}{ }^{-1}$. The evolution of $\mathrm{H}_{2} \mathrm{~S}$ producing bacteria in test $\mathrm{B}$, with a lower starting microbial population, was similar to test A. After 12 days, the difference in microbial counts between treated and control samples was greater than $1.5 \mathrm{log}$ $\mathrm{CFU} \mathrm{g} \mathrm{g}^{-1}$. Finally, in test $\mathrm{C}$ a much more intense inhibition occurred than in the other two tests. During the 12 days of storage the $\mathrm{H}_{2} \mathrm{~S}$ producing bacteria counts on fish samples with antimicrobial edible coatings were $<1 \log \mathrm{CFU} \mathrm{g}{ }^{-1}$ which was significantly lower than the counts for the control which progressively increased from $\geq 4.46 \log \mathrm{CFU} \mathrm{g}^{-1}$ at the 4th day of storage up to $\geq 8.11 \log \mathrm{CFU} \mathrm{g}^{-1}$ at the $12^{\text {th }}$ day. Thus, in this bacterial group the effect of the initial microbial load on the efficacy of the antimicrobial edible coatings was notable.

The overall results presented in herein confirm the potential of edible coatings enriched with OEO and $\mathrm{CV}$ to reduce the growth rate of all bacterial groups examined (mesophilic, psychrotrophic, Pseudomonas spp., Enterobacteriaceae, LAB and $\mathrm{H}_{2} \mathrm{~S}$ producing bacteria); therefore improving the microbiological quality of fish in cold storage. The extension of that reduction depended on the initial microbial concentration. When
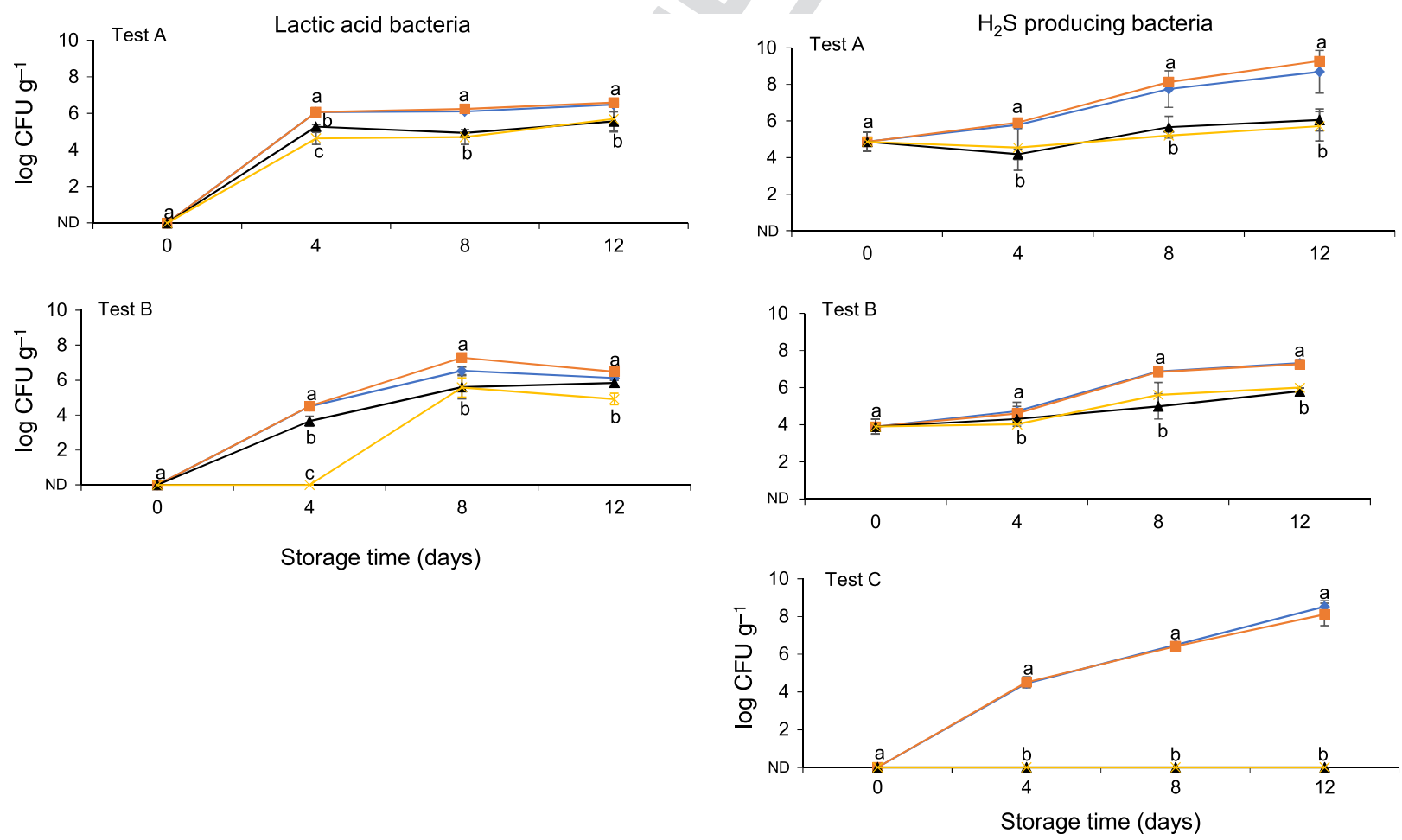

Figure 4 Total Lactic acid bacteria and $\mathrm{H}_{2} \mathrm{~S}$ producing bacteria counts (tests: A, B and C) for 12 days of cooling at $4{ }^{\circ} \mathrm{C}$. Test $\mathrm{C}$, is not included in the figure of Lactic acid bacteria, because no bacterial growth was detected in the samples. C: uncoated control; WPI, WPI coating; WPI + OEO, coating with WPI and OEO; WPI + CV, coating with WPI and CV. Different letters (a, b) indicate significant differences between treatments. WPI, Whey Protein Isolate; OEO, Oregano essential Oil; CV, Carvacrol. $\diamond$-C; 1 -WPI; $\boldsymbol{\Delta}$-WPI + OEO; $\times$-WPI + CV. ND, nondetectable. 
using low or intermediate initial microbial quality (tests A and B) there was a reduced impact in the bacterial growth. In the cases of psychrotrophic bacteria and Pseudomonas spp. the reduction was not significant, although in LAB and Enterobacteriaceae it was. However, in all cases the growth inhibition was much lower than when the initial microbial quantity was high (test $\mathrm{C}$ ). For test $\mathrm{C}$, results showed that the antimicrobial coatings inhibited the growth of some groups (Enterobacteriaceae and $\mathrm{H}_{2} \mathrm{~S}$ producing bacteria) and significantly reduced the growth rate of the others. Therefore, the effectiveness of the antimicrobial edible coatings was directly related to the initial bacterial population. Thus, we see how the combined effect of a reduced initial microbial load together with an antimicrobial coating significantly controlled the microbial quality of fresh fish. With the effects of the combination of preservation technologies elucidated in these results the marketable shelf-life of fresh fish could potentially be increased.

Low effectiveness of antimicrobial coatings has been found in the literature, yet these low levels of efficacy could have been related to poor initial microbial quality. Bensid et al. (2014) indicated that at day 3 of fish conservation batches treated with OEO, a mesophilic bacteria population of $6.04 \log \mathrm{CFU} \mathrm{g} \mathrm{g}^{-1}$ exceeding the maximum commercial limit $\left(6 \log \mathrm{CFU} \mathrm{g}^{-1}\right)$ was detected. The same behaviour was observed in psychrotrophic bacteria $\left(6.15 \log \mathrm{CFU} \mathrm{g}^{-1}\right)$. Iturriaga et al. (2012) reported that OEO had no inhibitory effect against two bacteria associated with the deterioration of fish (Pseudomonas fluorescens and Aeromonas hydrophila) and against Listeria innocua. The low initial microbial load present in fresh fish in this study $\left(>4 \log \mathrm{CFU} \mathrm{g}^{-1}\right.$ ) could have affected the efficacy of the antimicrobial coating treatment. In our lab, Carrión-Granda et al. (2018) reported an improvement in the efficiency of antimicrobial edible coatings combined with MAP technology in hake when special care with the fillet hygiene was taken, thus resulting in a reduced initial microbial load.

Results from test $\mathrm{C}$ are consistent with the data published by Hosseini et al. (2016) which reported that an edible coating enriched with OEO applied to fresh fish significantly delayed bacterial growth during 12 days of storage. The initial bacterial load was $\geq 3$ $\log \mathrm{CFU} \mathrm{g} \mathrm{g}^{-1}$ for mesophilic bacteria and $\geq 2 \log$ $\mathrm{CFU} \mathrm{g}{ }^{-1}$ for psychrotrophic bacteria. Jasour et al. (2015) significantly reduced initial bacterial load on uncoated samples of fresh fish and reported mesophilic (3.43 $\log \mathrm{CFU} \mathrm{g^{-1 }}$ ) and psychrotrophic bacteria counts (3.33 log $\mathrm{CFU} \mathrm{g} \mathrm{g}^{-1}$ ) similar to test $\mathrm{C}$ of our research. They reported that the antimicrobials evaluated had a significant effect during 16 days of storage. It is likely the reduction of the microbial load had a positive effect on these results.
The results of this paper also indicate that there were no significant differences between of the use of $\mathrm{OEO}$ and $\mathrm{CV}$ as an antimicrobial agent applied on fish through edible coatings. Since the concentration of CV was the same in both OEO and CV coatings, the action of the other compounds present in OEO (6.82\% p-cimene, $2.19 \%$ thymol, $0.02 \%$ eugenol) was considered negligible as compared to the action of $\mathrm{CV}$ $(72.23 \%)$. In addition, the presence of a WPI coating without antimicrobial agent did not have any effect on the evolution of the microbial population. This was expected since WPI does not have any known antimicrobial activity.

\section{Conclusions}

In conclusion, we see how a reduction of the microbial load by itself had a limited effect on the evolution of the microbial quality (higher CFU quantities), although it was very effective on the $\mathrm{LAB}$ group. In addition, it has been demonstrated that the effectiveness of the antimicrobial coatings was much higher when the surface of the fish had a very low initial microbiological load (experiment $\mathrm{C}$ ), which implied a synergistic effect between both technologies. It can be concluded that in order to ensure an increase in the commercial life of fresh fish through antimicrobial edible coatings, the fish has to be handled hygienically before the treatment and/or had to be subjected to a superficial disinfection process. Herein we see how, in addition, no significant differences were found between the antimicrobial effects of coatings with OEO or CV at the same concentrations, demonstrating that the possible synergistic effect of the other components of the OEO had no significant impact.

\section{Acknowledgments}

We are grateful to the National Secretary of Higher Education, Science, Technology and innovation of Ecuador (Secretaría Nacional de Educación Superior, Ciencia, Tecnología e Innovación de Ecuador) for the PhD scholarship.

\section{References}

Aponte, M., Anastasio, A., Marrone, R., Mercogliano, R., Peruzy, M.F. \& Murru, N. (2018). Impact of gaseous ozone coupled to passive refrigeration system to maximize shelf-life and quality of four different fresh fish products. $L W T, \mathbf{9 3}, 412-419$.

Bakkali, F., Averbeck, S., Averbeck, D. \& Idaomar, M. (2008). Biological effects of essential oils - A review. Food and Chemical Toxicology, 46, 446-475.

Bensid, A., Ucar, Y., Bendeddouche, B. \& Özogul, F. (2014). Effect of the icing with thyme, oregano and clove extracts on quality parameters of gutted and beheaded anchovy (Engraulis encrasicholus) during chilled storage. Food Chemistry, 145, 681-686. 
Boziaris, I.S. \& Parlapani, F.F. (2017). Chapter 3 - Specific spoilage organisms (SSOs) in fish. In: The Microbiological Quality of Food, Woodhead Publishing Series in Food Science, Technology and Nutrition. (edited by A. Bevilacqua, M.R. Corbo \& M. Sinigaglia) Pp. 61-98 ???: Woodhead Publishing.

Bremer, P.J. \& Osborne, C.M. (1998). Reducing total aerobic counts and Listeria monocytogenes on the surface of king salmon (Oncorhynchus tshawytscha). Journal of Food Protection, 61, 849-854.

Burt, S. (2004). Essential oils: their antibacterial properties and potential applications in foods-a review. International Journal of Food Microbiology, 94, 223-253.

Carrión-Granda, X., Fernández-Pan, I., Mezquita, S., Rovira, J. \& Maté, J.I. (2017). Development of whey protein isolate films incorporated with rosemary extracts to improve the microbiological quality of fresh tuna. MOJ Food Processing \& Technology, 5, 1-8.

Carrión-Granda, X., Fernández-Pan, I., Rovira, J. \& Maté, J.I. (2018). Effect of antimicrobial edible coatings and modified atmosphere packaging on the microbiological quality of cold stored hake (Merluccius merluccius) fillets. Journal of Food Quality, 2018, 1-12.

European Commission. (2005). Commmission regulation No 2073/ 2005 of 15 November 2005 on microbiological criteria for foodstuffs. Journal of the European Union, L322, 1-19.

FAO/WHO. (2008). Benefits and risks of the use of chlorine containing disinfectants in food production and food processing (Rep. No. 11357). World Health Organization. Shao. Report of a Joint Expert Meeting, 1-5.

Hosseini, S.F., Rezaei, M., Zandi, M. \& Ghavi, F.F. (2016). Effect of fish gelatin coating enriched with oregano essential oil on the quality of refrigerated rainbow trout fillet. Journal of Aquatic Food Product Technology, 25, 835-842.

ICMSF. (2005). Microorganisms in Food 6: Microbial Ecology of Food Commodities. New York, NY: Kluwer Academic/Plenum Publishers.

Iturriaga, L., Olabarrieta, I. \& de Marañón, I.M. (2012). Antimicrobial assays of natural extracts and their inhibitory effect against Listeria innocua and fish spoilage bacteria, after incorporation into biopolymer edible films. International Journal of Food Microbiology, 158, 58-64.

Jasour, M.S., Ehsani, A., Mehryar, L. \& Naghibi, S.S. (2015). Chitosan coating incorporated with the lactoperoxidase system: an active edible coating for fish preservation. Journal of the Science of Food and Agriculture, 95, 1373-1378.

Kilincceker, O., Dogan, I.S. \& Kucukoner, E. (2009). Effect of edible coatings on the quality of frozen fish fillets. $L W T$ - Food Science and Technology, 42, 868-873.

Özean, M. \& Erkmen, O. (2001). Antimicrobial activity of the essential oils of Turkish plant spices. European Food Research and Technology, 212, 658-660.

Ozogul, Y. \& Uçar, Y. (2013). The effects of natural extracts on the quality changes of frozen chub mackerel (Scomber japonicus) burgers. Food and Bioprocess Technology, 6, 15501560.

Pyrgotou, N., Giatrakou, V., Ntzimani, A. \& Savvaidis, I.N. (2010). Quality assessment of salted, modified atmosphere packaged rainbow trout under treatment with oregano essential oil. Journal of Food Science, 75, M406-M411. 


\section{Graphical Abstract}

The contents of this page will be used as part of the graphical abstract of html only. It will not be published as part of main.

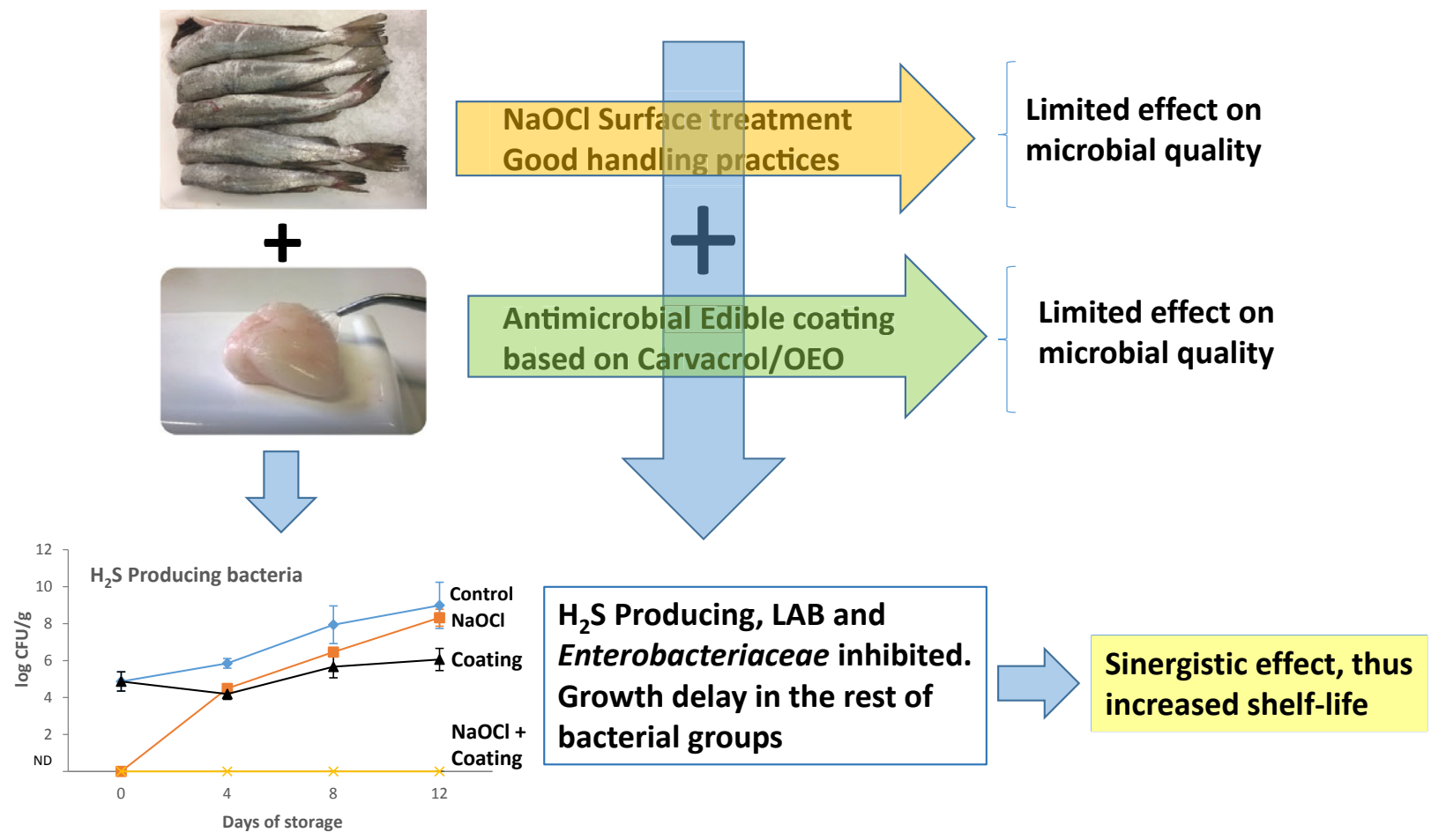

$5 \mathrm{XXX}$ 